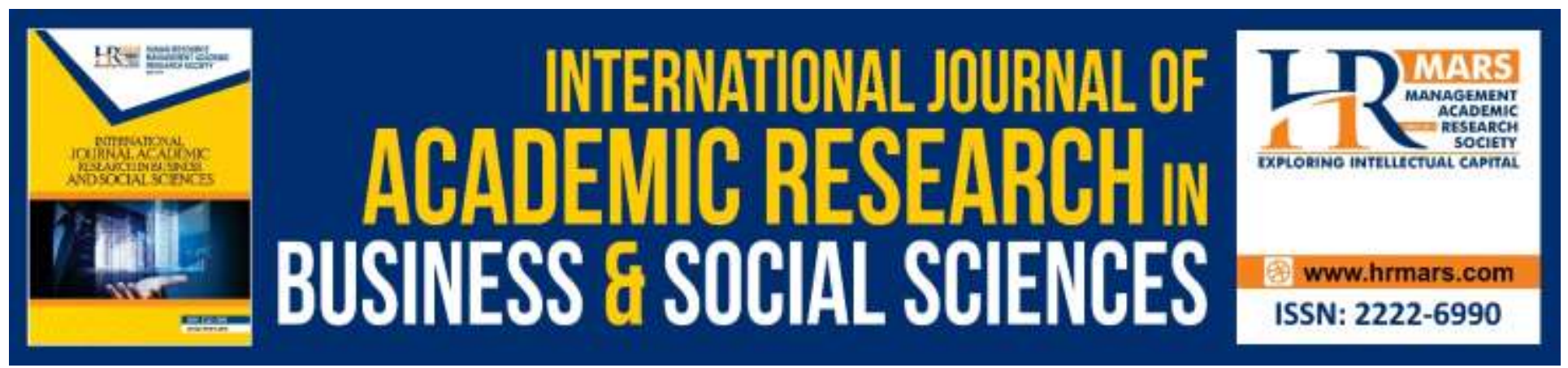

\title{
Free Instructional Resources Provision on Equity in Access to Education in Primary Schools in Marakwet Sub County, Kenya
}

Cheserek Peris Jeruto, Edward M. Okirima

To Link this Article: http://dx.doi.org/10.6007/IJARBSS/v10-i2/6952

DOI:10.6007/IJARBSS/v10-i2/6952

Received: 18 January 2020, Revised: 03 February 2020, Accepted: 12 February 2020

Published Online: 29 February 2020

In-Text Citation: (Jeruto \& Okirima, 2020)

To Cite this Article: Jeruto, C. P., \& Okirima, E. M. (2020). Free Instructional Resources Provision on Equity in Access to Education in Primary Schools in Marakwet Sub County, Kenya. International Journal of Academic Research in Business and Social Sciences, 10(2), 597-623.

Copyright: @ 2020 The Author(s)

Published by Human Resource Management Academic Research Society (www.hrmars.com)

This article is published under the Creative Commons Attribution (CC BY 4.0) license. Anyone may reproduce, distribute, translate and create derivative works of this article (for both commercial and non-commercial purposes), subject to full attribution to the original publication and authors. The full terms of this license may be seen

at: http://creativecommons.org/licences/by/4.0/legalcode

Vol. 10, No. 2, 2020, Pg. 597 - 623

http://hrmars.com/index.php/pages/detail/IJARBSS

JOURNAL HOMEPAGE

Full Terms \& Conditions of access and use can be found at http://hrmars.com/index.php/pages/detail/publication-ethics 


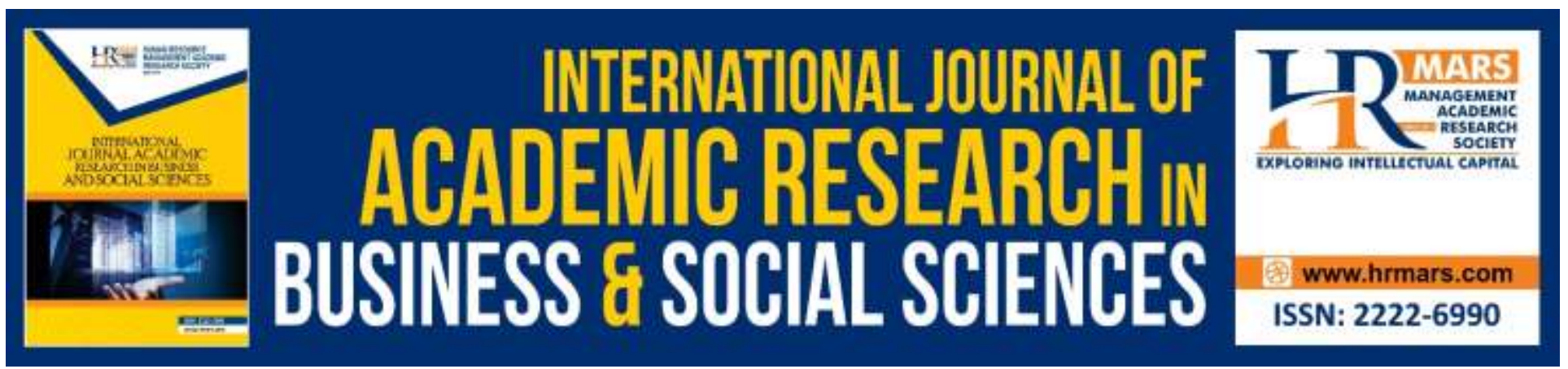

\title{
Free Instructional Resources Provision on Equity in Access to Education in Primary Schools in Marakwet Sub County, Kenya
}

\author{
${ }^{1}$ Cheserek Peris Jeruto, ${ }^{2}$ Prof. Edward M. Okirima \\ ${ }^{1}$ Degree of Master of Educational Planning, Management and Administration \\ ${ }^{2}$ Lecturer, Mount Kenya University
}

\begin{abstract}
Free primary education (FPE) in Kenya came into being in the year 2003. The introduction of the policy was aimed at realizing the Millennium Development Goals (MDGs) and Education for All (EFA) objectives before the year 2015. FPE was mooted with the idea of promoting equity and access to education by all children despite their economic background, gender, geographical location among other factors but its effect in promoting equity has been the subject for inquiry by many scholars although no study has been undertaken to look at the contribution of FPE on promotion of equity in primary in Marakwet Sub County, Elgeyo-Marakwet County, Kenya. The purpose of the study was to evaluate the effect of free instructional resources provision on Equity in access to education in primary schools in Marakwet Sub County, Elgeyo-Marakwet County, Kenya. The study was guided by Rawls Theory of Justice. The study was conducted in primary schools in Marakwet Sub County involving 99 schools. The study used cross-sectional survey research design technique. The target population comprised of head teachers, Sub County Education Officer (DEO), Parents Teachers Representatives (PTA) and teachers of selected schools within the Sub County. The sample size comprised of 30 head teachers, 30 PTA officials, 1 DEO and 197 teachers. Purposive and systematic sampling techniques were used in selecting respondents. Questionnaires, interview schedules and document checklists were instruments for data collection. Instruments were tested for validity and reliability before field data collection. Data collected was analyzed using descriptive (frequencies, percentages, means and standard deviation) and inferential statistics (Multiple linear Regression) with the aid of SPSS (Version 20.0) computer programme. The findings were presented using tables, pie charts and graphs. MLR result showed that $12.3 \%$ of the Equity in access to education in primary schools was accounted by availing of instructional resources. The study recommends that there be an increase in vote heads for tuition support, infrastructure and teacher recruitment to ensure equity in education access in primary schools in the study area. The findings of the study will help the Ministry of Education on proper management and implementation of FPE Policy towards promoting
\end{abstract}


INTERNATIONAL JOURNAL OF ACADEMIC RESEARCH IN BUSINESS AND SOCIAL SCIENCES

Vol. 10, No. 2, Feb, 2020, E-ISSN: 2222-6990 @ 2020 HRMARS

equity in primary schools. The children rights to participation in free primary education will also be supported through the study findings.

Keywords: Instructional, Resources, Equity, Education, Schools.

\section{Introduction}

Education matters greatly for almost every aspect of progress in human development. It is argued that progress in health and material well-being are to some extent driven by progress in the education (Lutz Cuaresma, \& Sanderson, 2008). UNESCO (2005) observed that Sub-Sahara Africa (SSA) is lagging behind other continents in achieving the Dakar Education for All (EFA) and Millennium Development Goals (MDGs). This is due to the enormous challenges the continent is facing in achieving development as a whole. Poverty, bad governance, conflict and the HIV/AIDS pandemic have made the task of raising the development levels of Africa even more difficult to accomplish. It is acknowledged that most of the children out of school, the illiterate school dropouts are in Sub-Sahara Africa (Riddell, 2003).

Makori (2005) argues that there are pupils' groups that are particularly disadvantaged in terms of access, retention and performance in education. These include the poor, rural populations, the physically challenged, orphans and people in armed conflict and post conflict situations. Both boys and girls in these categories are affected (UNESCO, 2005). UNESCO notes that due to the unequal socio-economic gender construct in most Sub Saharan African countries, the scale of disadvantages is tipped more against girls and women. Numerous studies have illustrated this situation to the point that education policy makers and practitioners have been forced to accept that there are serious gender disparities in education that call for urgent action if Africa is to be counted among those who will have achieved the EFA and MD goals by 2015 (Kremer, Moulin \& Namunyu, 2002; Joseph \& Francis, 2015; Limukii \& Mualuko, 2012).

According to right to basic education, primary education should be accessible to all (UNESCO, 2005). Hence, there should be elimination of discrimination of all forms and exclusion from enjoyment of this right, regardless of one's social or economic status, region or gender (Oketch \& Ngware 2010). Schools should be safe, physically reachable and affordable to all. Through the FPE policy, the government is tasked with ensuring that all children have equal access to education and address existing barriers in order to provide substantial access and quality education for all. Self-selection issues tend to hinder clean identification (Glewwe 2002; Glewwe \& Kremer 2006).

Reviewed studies (Riddell, 2003; World Bank, 2004; Raja \& Burnett, 2004; Kikechi, Andala, Chepkwony \& Simiyu 2012) have shown that majority of countries across the world enacted universal primary educational reforms in the past 30 years. This has been spearheaded by EFA and Millennium development goals. Marakwet Sub County has got 99 public primary schools of which some are day, mixed or single boarding schools.

Since introduction of FPE policy in 2003 and now it is in its 13th year, statistics from Sub County Education Office (2014) shows that enrolment has increased significantly over the years. In 2003, 7,296 pupils enrolled in class 1, it increased to 9,646 by 2007 but as per 2013, only 6,622 enrolled in class 1 in 2013. This shows that enrolment levels in primary school are on declining trend. Issues of equity in access to education to all pupils irrespective of their social economic background, disability status, gender profile or background characteristics have not been adequately addressed and in 
INTERNATIONAL JOURNAL OF ACADEMIC RESEARCH IN BUSINESS AND SOCIAL SCIENCES Vol. 10, No. 2, Feb, 2020, E-ISSN: 2222-6990 @ 2020 HRMARS

Marakwet West Sub County. Therefore, this study investigated the effect of free instructional resources provision on Equity in access to education in primary schools in Marakwet Sub County.

\section{Statement of the Problem}

Statistics on enrolment rate, retention and completion rates in Marakwet Sub County primary schools fail to indicate whether equity has been achieved in ensuring primary education access (Republic of Kenya, 2005). For example, the enrolment rate in the Sub County had slumped to 6622 in 2013 as opposed to 7296 in 2003 (RoK, 2013). This is despite the government providing instructional materials, human resource and infrastructure support to schools to enable the implementation of FPE policy. However, the question is whether all pupils in primary schools despite their gender, poverty level, disability, region disparity among other factors are getting their share of public spending on free primary education in Marakwet Sub County, a focus of this study.

In addition to this, it is noted that since FPE policy was started in 2003 in Kenya, it has experienced some shortcomings besides its success in ensuring that all non-school going children enrolled in schools (Limukii and Mauluko, 2012). However, parents have in the past blamed the government for lack of control on the education system which is getting very expensive, with schools charging fees as they please (UNESCO, 2005). While a lot has been written by the government on the success of the FPE in Kenya, implementation problems continue to be experienced at the grassroots level (Glewwe and Kremer, 2006). Inadequate research has been conducted in determining the contributions of free primary education policy towards promoting equity based on pupils' enrolment to schooling, their retention and completion in Marakwet Sub County. This study determines the way equity in education access has been achieved through FPE policy in Marakwet primary schools.

\section{Objective of the Study}

The objective of the study was to evaluate the effect of free instructional resources provision on Equity in access to education in primary schools in Marakwet Sub County

\section{Research Hypothesis}

I. How does provision of free instructional resources influence Equity in access to education in primary schools in Marakwet Sub County

\section{Theoretical Review}

John Rawls 'Theory of Justice' guided the study. Rawls's theory of justice (2001) can be used as a basis for considering fairness and justice before considering the legal, economic and educational aspects of equity in access to basic primary education. Rawls's theory provides a framework for moral reasoning about fairness within democratic societies that can be applied to defining the public interest in equity in schools, colleges, and students (St. John, 2006) and a moral lens for thinking about current education policy choices. Rawls (2001) used two principles as a means of finding balance among competing claims about justice.

These principles are restated below with an explicit emphasis on education: Principle One relates to basic rights, which all individuals have in a democratic society. The right to an education is nearly universally accepted (Nussbaum, 1999). Applied to education in Kenya, we need to consider the basic right to primary education for all pupils before considering equal rights to secondary access for those 
INTERNATIONAL JOURNAL OF ACADEMIC RESEARCH IN BUSINESS AND SOCIAL SCIENCES Vol. 10, No. 2, Feb, 2020, E-ISSN: 2222-6990 @ 2020 HRMARS

who qualify academically. Principle two relates to equal opportunity, which argues that if there is an inequality it should favour the most disadvantaged. The historic emphases on equal opportunity in school desegregation and pupils' aid are a few of many examples of this approach in education policy to address differences in education.

In addition, Rawls used a "just savings principle" to discussion the mechanisms for promoting crossgeneration equity. He argued for using taxation to support education as uplift across generations. However, this liberal view of taxation must be mitigated by awareness of the strong public resistance to excessive taxation. The right to an education is generally accepted as part of the basic rights implicit in Principle One. To understand the meaning of education as a human right, it is important to consider rights in context. In their discussions of women and developing countries, Nussbaum (1999) argue for basic rights to education and literacy.

Martha Nussbaum, an advocate of the capabilities approach, argues, "In short, the Rawlsian approach does not probe deeply enough to show us how resources do or do not go to work in making peoples able to function" (1999, p. 34). In her analysis of social justice for women in the developing world she defines education as a right: "Nothing is more important to women's life chance than education. With literacy, a woman may choose her options and to some larger extent shape her future" (p. 100). The capabilities approach, however, is not defined just by basic literacy, but by what it takes to function in society (with full economic citizenship).

Linking to this study, the Rawls theory promotes equity in education provision for all children irrespective of their socio, political or economic background to participate in free primary education. These groups of pupils might be those from; poor households, orphans, disabled and girls that have been discriminated for long. Therefore, the introduction of free primary education policy was aimed at addressing equity in education access although the situation in Marakwet Sub County primary schools remains unclear.

\section{Conceptual Framework}

The study conceptual framework is presented below showing the relationship between the independent variable; FPE policy and dependent variable: Equity in access to education in primary schools in Marakwet Sub County. Figure 1.1 presents the conceptual framework for the study. 
INTERNATIONAL JOURNAL OF ACADEMIC RESEARCH IN BUSINESS AND SOCIAL SCIENCES

Vol. 10, No. 2, Feb, 2020, E-ISSN: 2222-6990 ¿ 2020 HRMARS

Independent Variables

FPE policy

\section{Dependent Variable}

\section{Equity in access to \\ primary education}

Free provision of educational instructional facilities

- No. of teachers

- No of books availed

- Stationeries

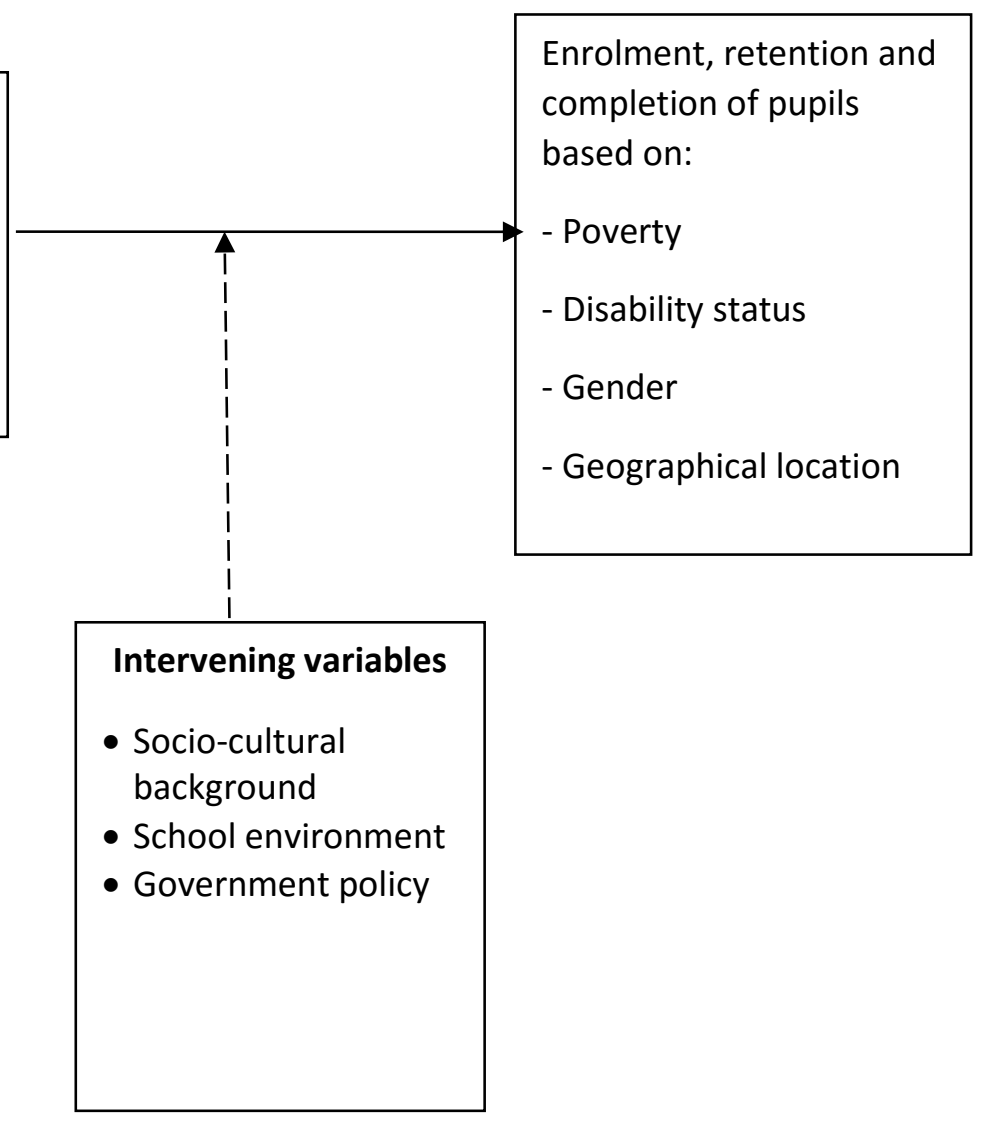

Figure 1 Conceptual Framework

Source: Author (2014)

\section{Intervening Variables}

The intervening variables in this study could affect the dependent variable in a variety of ways. Despite the provision of free primary education policy, some parents may be willing while others may not take their children to school due to socio-cultural practices. Another scenario that could happen is whereby the school environment does not support the inclusion of disabled pupils in schools, this would impact on disabled pupils (for example physical impaired) right to education as envisioned by national goals of education, EFA (Education for All) and Convention for Rights of Children (CRC) conventions. Therefore, it is assumed that the independent variables in this study have minimal effect or no effect on Equity in access to education in primary schools in Marakwet Sub County, ElgeyoMarakwet County. 
INTERNATIONAL JOURNAL OF ACADEMIC RESEARCH IN BUSINESS AND SOCIAL SCIENCES

Vol. 10, No. 2, Feb, 2020, E-ISSN: 2222-6990 @ 2020 HRMARS

\section{Empirical Review \\ Concept of Equity}

There are two broad conceptions of equity in relation to school funding and each of these is distinct from a concept of equality of opportunity. Taking 'equity' first: one definition of equity is 'horizontal equity' which stresses the need to treat similar people, or pupils in the case of schools, the same. The second definition is 'vertical equity' which encompasses the need to treat different pupils differently. Thinking in terms of school funding the former implies the same level of funding for pupils who are regarded as the same and the latter require different levels of funding for groups of pupils which are considered to have differential levels of need (Toutkoushian \& Michael, 2007).

The former definition of equity has tended to be seen as inadequate in debates about school funding. The pertinent point here is that equal school horizontal equity funding per-pupil is not necessarily genuinely equitable. As Hirth and Eiler (2005) put it:

The difference between equity and equality leads to profound differences in the definition of the problems to be addressed and the remedies available for their solution. In school finance the term equitable has come to refer to funding based on the needs of children. Spending the same number of dollars on each student is a form of equality, but it may not be equitable; some students necessitate greater expenditures (Hirth \& Eiler, 2005:15).

This is why in debates about equity and school funding it is vertical equity which has tended to be the policy objective (Williams, 2015). This is especially important given the evidence that increased funding can make a greater difference for pupils from low income households. One definition of vertical equity would be to simply allocate higher levels of funding to pupils from groups which have been shown to perform worse at school for example, those from lower income households. This would satisfy the requirements of a 'thin' version of horizontal equity. However, a more demanding goal would be for the school funding system to be targeted in such a way that it enables the achievement of equality of opportunity. This would be achieved where the educational and later lifechances for pupils are equal for all groups of pupils whatever their gender, household income and so on (Miller, 2005).

Building on the conceptual framework defined in the Organisation for Economic Cooperation and Development (OECD) Report No More Failures, equity in education can be seen through two dimensions: fairness and inclusion (Field, Kuczera \& Pont, 2007). Equity as inclusion means ensuring that all pupils reach at least a basic minimum level of skills. Equitable education systems are fair and inclusive and support their students to reach their learning potential without either formally or informally pre-setting barriers or lowering expectations. Equity as fairness implies that personal or socio-economic circumstances, such as gender, ethnic origin or family background are not obstacles to educational success. An equitable education system can redress the effect of broader social and economic inequalities. In the context of learning, it allows individuals to take full advantage of education and training irrespective of their background (Field, Kuczera \& Pont, 2007).

\section{Universal Primary Education (UPE)}

Human development is partly a matter of people and communities improving their own lives and taking greater control of their destinies (Chimombo, 2005). Education is broadly used as an instrument for social change. The critical point of such belief can be traced far back to the 1960s when 
INTERNATIONAL JOURNAL OF ACADEMIC RESEARCH IN BUSINESS AND SOCIAL SCIENCES Vol. 10, No. 2, Feb, 2020, E-ISSN: 2222-6990 @ 2020 HRMARS

Theodre Schultz systematically articulated the human capital theory of development. In his voluminously printed works, Schultz argued that population quality and knowledge constitute the principal determinants of the future welfare of mankind (Chimombo, 2005).

Adding to this argument, Harbison and Hanushek (1992) contended that a country which is unable to develop the skills and knowledge of its people and to utilize them effectively in the national economy will be unable to develop anything else. And according to Psacharopoulos and Woodhall (1985), education is widely regarded as the route to economic prosperity, the key to scientific and technological advancement, the means to combat unemployment, the foundation of social equity, and the spread of political socialization and cultural vitality.

One can also make up an intricate argument in that educating all the children provides stratificational costs to oneself and one's children since only in this way will one protect one's own rights. Equalizing the welfare of the individual in society is therefore an important modern desideratum. It was at the back of these rationales that African, Asian and Latin American governments expressed their intentions for Universal Primary Education (UPE) in the early 1960s. This movement was rekindled by the recent Jomtien and Dakar Education for All (EFA) conferences. The advocates of UPE contended that mass education will result in an increased supply of educated human power, accelerated economic growth, more social justice, reduced regional disparities, and improved social welfare. At any rate, all children will have an equal start in life regardless of sex, socio-economic background, or geographical location (Coombs, 1985). No wonder that as governments strived to reduce poverty and improve the lives of their people, they looked to education as the vehicle for achieving these objectives.

Article 26 of the 1948 UN universal declaration of human rights said that everyone has a right to education and that this education shall be free and compulsory. It went on to say that education shall be directed to the full development of the human personality and to the strengthening of respect for human rights and fundamental freedoms. If education is viewed as a human right, then EFA implies education for everybody since everybody must have that right. The challenge towards this drive is how to indeed make education available to all and in good quality. As regard to the purpose of that education, this is all about the role of education in peoples' future's lives (Kenya, 2008).

Chimombo (2005) argues that education has a great significance for the economic social and cultural development. The aim of educational policy should therefore be to give every person a chance of developing his/her inherent potential. It is that kind of education that will bring about inter alia accelerated economic growth, more wealth and income, decline in population growth, national unity and political stability. In contemporary societies, educational attainment is directly valued and is the main factor leading to advantage along all other key dimensions of individual stratification. Simply to be a member of the modern political economy requires that individuals receive large doses of mass schooling. Consequently, the state attempts to create large number of white-collar jobs, legimatizing urban forms of work and knowledge, and sanctions school credentials through a variety of licensing and employment rules. It is therefore desirable to give everyone education.

Access to free and compulsory education in Africa is a very big issue against the background that over $50 \%$ of primary school children in 47 least developed countries of the world do not have access to education (OECD, 1996). Fafunwa (2001) observes that in the sub Saharan region, over 40 million pupils of primary school going age are unable to enroll. Even amongst those enrolled; about $33 \%$ of 
them are unable to reach primary five before dropping out of school. In the African continent, the introduction of free compulsory and universal basic education led to increased primary school enrollment of students in secondary schools (UNESCO, 2003).

It is an undisputed fact that the abolition of primary school fees has led to vast enrollment gains in several countries. After fees were abolished in Malawi in 1994 and in Uganda in 1997, enrollment in both countries grew by 68 percent (Avenstrup, Liang \& Nellemann, 2004). Lesotho's graduated abolition of fees, beginning in 2000, led to a Grade 1 enrollment increase of 75 percent, and over 1 million students entered school in Kenya following fee abolition in 2003. Finally, in Cameroon and Tanzania, the gross enrollment ratios increased by 16 percent and 14 percent, respectively.

Bategeka (2005), in a policy case study, outlines Uganda's policy for UPE and its implementation which began in 1997. The author examines evidence of the impact of the UPE policy in terms of its results in improving access, equity and educational quality. Bategeka finds that whilst UPE improved access indicators substantially, quality indicators worsened following the introduction of UPE and have yet to recover to pre-UPE levels. Whilst gender equity improved markedly, inequities in financing education remain a key challenge.

In such cases, public funding of basic education can lead to greater equity and higher growth. Deninger (2003) suggests that the figures show that the policy resulted in a shift of the burden of education finance away from households and towards the public sector. The policy reduced the wealth bias that characterized access to primary education in 1992 and helped to establish greater equity by increasing girls' access and reducing the incidence of cost-related drop-out. A significant increase in delayed enrolments of overage pupils was also observed, further emphasizing the importance of cost for educational access. Primary school enrolments by the poor increased markedly when differences in enrolment by household income quintiles were considered. Gender bias in enrolment figures practically disappeared following the introduction of the UPE policy.

Kikechi et al., (2012) citing ROK (2005), Kenya is working towards the Millennium Development Goal (MDG) on education to ensure that, by 2015 , children everywhere, boys and girls alike, will be able to complete a full course of primary schooling. The indicators are (a) net enrolment in primary education-boys, girls, (b) proportion of pupils starting grade 1 who reach grade 5-boys, girls, and (c) literacy rates of 15- to 24-year olds-women, men. Apart from Universal Primary Education (UPE), MDG number 3 on promotion of gender equality and empowering women aims at eliminating gender disparity in primary and secondary education by 2005 and at all levels of education by 2015 .

\section{Free Instructional Support and Equity in access to Education}

To realize quality education, necessary inputs must be in place. Key to the inputs are enough and relevant books for teachers and the learners to support curriculum implementation. This issue again brings disparity among schools in developed and the less developed countries and in different regions and locations. The developed countries donate books to the poor countries. These donations cannot be taken as an act of philanthropy but it is meant to create space in their libraries for more stock of books (Ahmed \& Sayed, 2009). This explains why books donated are outdated and are not in line with the curriculum of the beneficiary countries. The burden of providing books and other learning and teaching resources is on the government and the parents (Courtney, 2008). This is a big challenge in poor countries that are already struggling to cope. Sufficiency of these materials in schools cannot be 
INTERNATIONAL JOURNAL OF ACADEMIC RESEARCH IN BUSINESS AND SOCIAL SCIENCES Vol. 10, No. 2, Feb, 2020, E-ISSN: 2222-6990 @ 2020 HRMARS

assured and this compromises the goal of providing Universal Quality Education as only the privileged few benefits from quality education. Quality education cannot therefore be said to be universal.

Teachers are the defining factor in determining the quality of education provided to children. Many teachers have not received adequate training or achieved the level of education needed to become qualified. A 2008 study found that in Afghanistan, Angola, Nepal and Southern Sudan fewer than half of teachers (42\%) had been to secondary school, let alone received teacher training. An estimated 1.9 million new teachers are required annually to achieve universal primary education by 2015 . The boost in enrolment rates has increased the numbers of untrained teachers that are teaching childrenwith negative effects on the quality of learning and the protection of children from abuse and mistreatment. Where teachers have low pay and status, incentives can be used to build their confidence and self-esteem (for example, teacher housing or support for continuing education) while better terms and conditions are secured.

The Ministry of Educations position is that the textbook/pupil ratio for lower primary has improved from one textbook for more than 10 pupils before 2003 to 1:3 by 2007, reaching 1:2 in 2008 and 2009. For upper primary, TPR has improved from 1:2 in 2007 to almost 1:1 in 2008 and 2009 for the majority of schools. However, these have weakened sharply since 2009, and small schools do not benefit from economies of scale, and have ratios far higher than this (Value for Money Audit Report, 2009). This confirms the teachers' position that instructional resources are grossly insufficient. The Ministry of Education admits that, in fact, the budgetary allocation by the Government of Kenya through the Ministry for the sector is insufficient and this does impact negatively on the provision of resources such as textbooks, PTRs and Retention Rates are also affected (Republic of Kenya, 2010). Njeru, (2013) further identified that the problem of inadequate number of qualified teachers comes out strongly because it is not only significant but also positively related to failure rate. This really affects performance and hence leads to high failure rates. The real problem here is if these pupils are taught by an unqualified staff, they are likely not to understand and hence will fail. The issue however that needs attention is the human resource. Most of the teachers who are qualified, are not willing to be transferred to far away schools, where there are not only no incentives but also working conditions are also poor. In addition, some regions are simply not attractive to teach in, like northern Uganda. For example, 500 teaching positions were advertised in Kitgum, but only 210 were submitted, and only 180 were deemed suitable (Bategeka, 2005).

The increased number of pupils affected teachers since they now had to deal with increased workloads. The increased responsibilities without an equivalent raise in their remuneration had demotivated many of them (Kenya, 2008). Teachers were not able to give individual attention to the learners especially the slow ones, hence affecting the quality of learning. There is also an acute shortage of teachers because of the great increase in pupil enrolments. Most classes were too large to be handled by a single teacher. On average, the teacher pupil ratio in most schools was 1:70, which was a serious implication on learning and teaching (UNESCO, 2005).

Njeru, (2013) argues that efforts to improve education in the developing world typically focus on providing more inputs to schools. Despite this, substantial evidence has accumulated to show that increased funding is not sufficient for improved learning outcomes. Incremental funds may be allocated to inputs that have weak impacts on student learning. Teachers and other education personnel (which typically represent $75 \%$ or more of education spending) may be poorly motivated 
INTERNATIONAL JOURNAL OF ACADEMIC RESEARCH IN BUSINESS AND SOCIAL SCIENCES

Vol. 10, No. 2, Feb, 2020, E-ISSN: 2222-6990 @ 2020 HRMARS

to perform. A study of teacher absenteeism in nine developing countries found that, on any given day, $11-30 \%$ of teachers were absent from their posts.

\section{Research Methodology}

The study utilized a mixed methodology. According to Creswell (2003), mixed method refers to an emergent methodology of research that advances the systematic integration or 'mixing' of quantitative and qualitative data within a single investigation or sustained policy of inquiry. This involved use of qualitative and quantitative sources of information in determining effect towards promoting equity in public primary schools in Marakwet Sub County, Elgeyo-Marakwet County. The basic premise of this methodology is that such integration permits a more, complete, and synergistic utilization of data than do separate quantitative and qualitative data collection and analysis. The quantitative data were collected through questionnaires while qualitative data was collected using interview schedules.

\section{Research Design}

The study employed the cross-sectional survey. A survey design involves asking a large group of respondents' questions about a particular issue (Mugenda and Mugenda, 2003). According to Creswell (2003), a cross sectional survey design provides a quantitative or numeric description of trends, attitudes or opinions of a population by studying a sample of that population. From the sample results, the researcher generalizes to the population especially if the population is too large. The design has an advantage because it is easy to apply research instruments such as questionnaires and which allow for the collection of data from a large number of respondents in a relatively short period. The limitation of descriptive survey research is that it depends on cooperation of respondents.

\section{Location of the Study}

The study was conducted in Marakwet West Sub County, Keiyo-Marakwet County, Kenya. According to Kenya National Bureau of Statistics (KNBS) 2009 census, the Sub County has 332,465 people. The Sub County is inhabited by members of Marakwet community. The main economic activity is farming and livestock production. The Sub County headquarters is located at Kapsowar. There are several public amenities like 99 primary schools, 35 secondary schools, 3 health centres and 3 market centres. The study location was selected due to issues of increased population size that is not commensurate to increased literacy levels in the Sub County despite the introduction of FPE policy.

\section{Target Population}

According to the Sub County Education Officer, there are 99 public primary schools being funded by free primary education policy (RoK, 2014). Of these 11 are boarding schools while 88 are day primary schools. The population for the study comprised of Sub County Education Officer (DEO), parents' teacher representatives (PTA), head teachers, and teachers from all public primary schools in the Sub County.

According to DEO statistics, there are 99 head teachers and 656 teachers. One PTA member from each of 99 primary schools and the DEO acted as key informants for the study. Table 1 gives the target population for the study. 
INTERNATIONAL JOURNAL OF ACADEMIC RESEARCH IN BUSINESS AND SOCIAL SCIENCES Vol. 10, No. 2, Feb, 2020, E-ISSN: 2222-6990 @ 2020 HRMARS

Table 1 Target population

\begin{tabular}{ll}
\hline Respondents & Number \\
\hline Head teachers & 99 \\
Teachers & 656 \\
DEO & 1 \\
PTA & 99 \\
\hline Total & $\mathbf{8 5 5}$
\end{tabular}

Source: RoK (2014)

\section{Sampling Procedure and Sample Size}

According to Kerlinger (1986), a representative sample of $10-30 \%$ is ideal depending in a descriptive research. On this study basis, $30 \%$ of the target population was used to determine the sample size of PTA, head teachers and teachers (main respondents) for the study while the key informant DEO will be selected using census selection method. Table 3.2 gives the sample size and sampling procedures used.

Table 2 Target Population

\begin{tabular}{llll}
\hline Respondents & Target & Sample size & Sampling procedure \\
\hline Head teachers & 99 & 30 & Systematic random sampling \\
Teachers & 656 & 197 & Systematic random sampling \\
DEO & 1 & 1 & Purposive sampling \\
PTA & 99 & 30 & Systematic random sampling \\
\hline Total & $\mathbf{8 5 5}$ & $\mathbf{2 5 8}$ & \\
\hline
\end{tabular}

Source: RoK (2014)

Therefore, 197 teachers, 30 head teachers, 30 PTA representatives and 1 DEO formed the sample size for the study. The DEO who are key informants for the study were selected using purposive sampling. The head teachers, PTA representatives and teachers were selected using systematic random sampling. In a systematic sampling procedure, every $\mathrm{K}^{\text {th }}$ case of the population is selected for inclusion in the sample (Mugenda \& Mugenda, 1999).

To obtain a truly random sample, using this method, the list of all in the sampling frame first be randomized by the researcher. In selecting teachers to participate in the study, every $3^{\text {rd }}$ teacher from the 656 was selected to participate in the study. The same procedure was repeated for head teachers and PTA representatives. This method is popularly used in cases where a complete list of the population from which a sample is drawn is available (Kombo \& Tromp, 2006).

\section{Research Instruments}

The study utilized questionnaires, interview guides and document analysis as instruments for data collection. Questionnaires were prepared for teachers while interview schedules were for DEOs and PTA officials. The questionnaires were structured according to the objectives of the study. The study developed a Likert like scale for most of the questionnaire items for easy analysis of the data. In the scale, the points were awarded as follows: Strongly Agree $(S A)=5$; Agree $(A)=4$; Undecided $(U)=3$; Disagree $(D)=2$; Strongly Disagree $(S D)=1$. The interview schedules were used to get information 
INTERNATIONAL JOURNAL OF ACADEMIC RESEARCH IN BUSINESS AND SOCIAL SCIENCES

Vol. 10, No. 2, Feb, 2020, E-ISSN: 2222-6990 @ 2020 HRMARS

from PTA representatives, Head teachers and DEO. The interview documents were structured according to the objectives of the study and will involve open-ended questions. Document checklist was used to get information on enrolment, transition and completion rate of pupils in public primary schools in the Sub County.

\section{Validity and Reliability of Research Instruments Validity}

Validity has been defined by the extent to which a test measures what it claims to measure (Gregory, 1992). Therefore, validity is the degree to which results obtained from the analysis of the data actually represent the phenomenon under study (Orodho, 2003). If such data is a true reflection of the variables, then the inferences based on such data was accurate and meaningful. To ensure face validity of the research instruments, three members of the School of Education at the University who are experts in this area of study scrutinized the research instruments.

Their suggestions were used in revising the questionnaires before preparing the final copy. Face validity is a non-statistical assessment of whether or not a test appears to be valid. This concept is not an index of validity at all; rather it simply addresses the nonprofessional acceptability of a measure (Gregory, 1992).

\section{Pilot Study}

Before the instruments were used to collect the data for the study, a pilot study was conducted in one school in the neighboring sub county (Keiyo). This was to ensure that the study got the intended information from the questionnaires. The pilot study helped in identifying problems respondents would encounter while filling them. A pilot study also provides data for making estimates of time and the cost for completing various phases of the research (Gall and Borg, 1996). The number of respondents for the pilot study should be between $9 \%-10 \%$ of the sample population (Gall and Borg, 1996). In this study, a total of 4 respondents from a school that was not involved in the actual research were used for the pilot study. Through pilot study, the researcher conducted reliability tests and also had a chance to familiarize herself with the respondents before commencing on the major study.

\section{Reliability of Research Instruments}

Reliability is a measure of degree to which research instruments yields consistent results or data after repeated trials or the degree to which test scores are free from measurement errors. A cross disciplines competent researchers not only fail to report the reliability of their measures (Nunnally \& Bernstain, 1994), but also fall short of grasping the inextricable link between reliability and effective research. The test-retest method was employed to establish the reliability of the questionnaires. The technique involves administering the same instrument twice to the same group of subjects (Gregory, 1992).

The most critical problem with this method is to determine the correct delay between the two administrations of measure (Gall and Borg, 1996). If the re-test is administered too soon after the initial test, students may recall their responses to many of the items, which will tend to produce artificially high reliability coefficient. On the other hand, if the re-testing is delayed too long there is a good possibility that the students' ability to answer some items will change, and this may lead to lower reliability coefficient (Crocker and Algina, 1986). A period of two to four weeks is the most 
appropriate for most social researchers (Gregory, 1992). This study used an interval of two weeks period to conduct reliability tests. According also to Kothari (2004), if 10-20 items are used, the minimum reliability value should be between $0.6-0.80$. The study used a benchmark of 0.7 as a basis for determining the reliability of research instrument. According to the results of the reliability studies, an average Cronbach alpha correlation coefficient value of 0.869 was obtained for the teachers' research questionnaire. Slight modifications were made to the research instruments before final administration to the field.

\section{Data Collection Procedures}

The study sought research clearance letter from Mount Kenya University School of Post Graduate Studies to facilitate research permit. Thereafter, permit to conduct research was obtained from National Commission for Science, Technology and Innovation (NACOSTI) to spearhead easy data collection process. The Sub County Director of Education was notified and later accepted the research to be conducted in primary schools. The head teachers of identified primary schools were contacted prior to data collection to give permission to administer questionnaires and conduct interviews in their schools.

The researcher visited selected schools with the questionnaires to be administered and request the school administration to assist, in identifying teachers' to be included in the research. Thereafter, questionnaires were administered to teachers by researcher guiding them accordingly. Finally, questionnaires were collected the same day with the maximum day being kept at two days. Interview sessions were conducted with head teachers and DEO at their requests. Document analysis was used to collect data on enrolment patterns across the years.

\section{Data Analysis}

Data from the field was organized and arranged well to ensure easy data coding, entry and analysis process. The data analysis was both in qualitative and quantitative forms. Quantitative data were analyzed using descriptive and inferential statistics. Data was analyzed using descriptive statistics (frequencies, percentages, means and standard deviations, and inferential statistics (multiple regression analysis) were utilized. The Multiple Linear Regression, denoted by MLR is presented here:

Where:

$$
y=a++\beta_{1} x_{1}++\varepsilon
$$

$$
\begin{aligned}
& y=\text { equity in education access } \\
& \alpha=\text { Y-intercept (a constant term) } \\
& \beta_{1}=\text { Slope parameter } \\
& x_{1}=\text { free provision of instructional resources } \\
& \varepsilon=\text { Residual (random error term) }
\end{aligned}
$$

All tests were performed at $95 \%$ confidence level with significant differences were recorded at an alpha $\alpha$-level of $0.05(p<0.05)$ for MLR. For descriptive and inferential statistics, the study examined all the completed questionnaires, and the information contained therein were tabulated in frequency tables, pie charts and bar graphs. The qualitative data from interview schedules were analyzed using content analysis as per the objectives of the study. 


\section{Ethical Considerations}

All ethical conducts pertaining the research process were followed. First, permission to carry out the study was sought after presentation of study proposal at Mount Kenya University. Thereafter, research permission was sought from National Commission for Science, Technology and Innovation (NACOSTI) in Nairobi, Marakwet Sub County Education Office and headteachers of selected schools within the Sub County. To the respondents, the nature and purpose of the study were explained to the respondents by the researcher. The researcher treated all the information given by the respondents with a lot of confidentiality to safeguard the respondent's personal integrity concerning University's ethical considerations. Respondents' privacy and confidentiality was upheld during the study process.

\section{Research Findings and Discussions}

\section{Demographic Characteristics of Teachers}

It was important to determine the salient and general characteristics of respondents who participated in the study based on their gender category, age in years, highest level of education and training, working experience and the class to which they represented. Initially, the teachers were requested to indicate their gender. The results are presented in Figure 2.

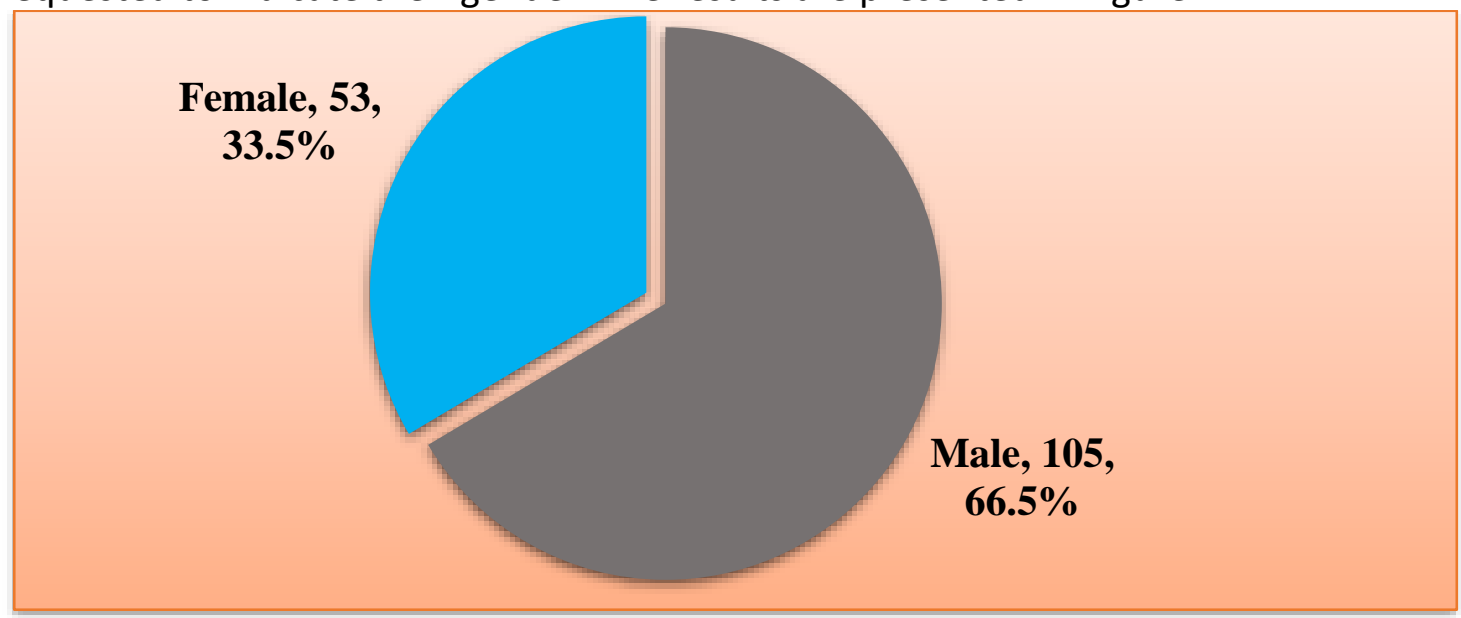

Figure 2 Gender of respondents

According to the findings in Figure 2, most 105 (66.5\%) of teachers who participated in the research were male as opposed to 53 (33.5\%) who were female. The low response and participation by female teachers were due to location of majority of schools that are classified to be disaster risk-prone areas.

\section{Age Category}

The study also requested the teachers to give their age profiles. Their responses are illustrated in Table 3. 
INTERNATIONAL JOURNAL OF ACADEMIC RESEARCH IN BUSINESS AND SOCIAL SCIENCES Vol. 10, No. 2, Feb, 2020, E-ISSN: 2222-6990 @ 2020 HRMARS

Table 3 Teachers age category

\begin{tabular}{lll}
\hline Category & Frequency & Percent \\
\hline $20-29$ years & 43 & 27.2 \\
$30-39$ years & 35 & 22.2 \\
$40-49$ years & 64 & 40.5 \\
$50 y r s$ and above & 16 & 10.1 \\
\hline Total & $\mathbf{1 5 8}$ & $\mathbf{1 0 0 . 0}$ \\
\hline
\end{tabular}

Results from Table 3 show that most 64 (40.5\%) were aged between 40-49 years, 43 (27.2\%) were found to be aged $20-29$ years, 35 (22.2\%) were found to be aged 30 -39 years while $16(10.1 \%)$ were found to be aged more than 50 years. This shows that all categories of teachers based on their age bracket opinions and perceptions on the effect of primary school education policy were captured in the study.

\section{Level of Education of Teachers}

The study also sought to find out the level of education of teachers in Marakwet Sub County primary schools. The findings are presented in Figure 3.

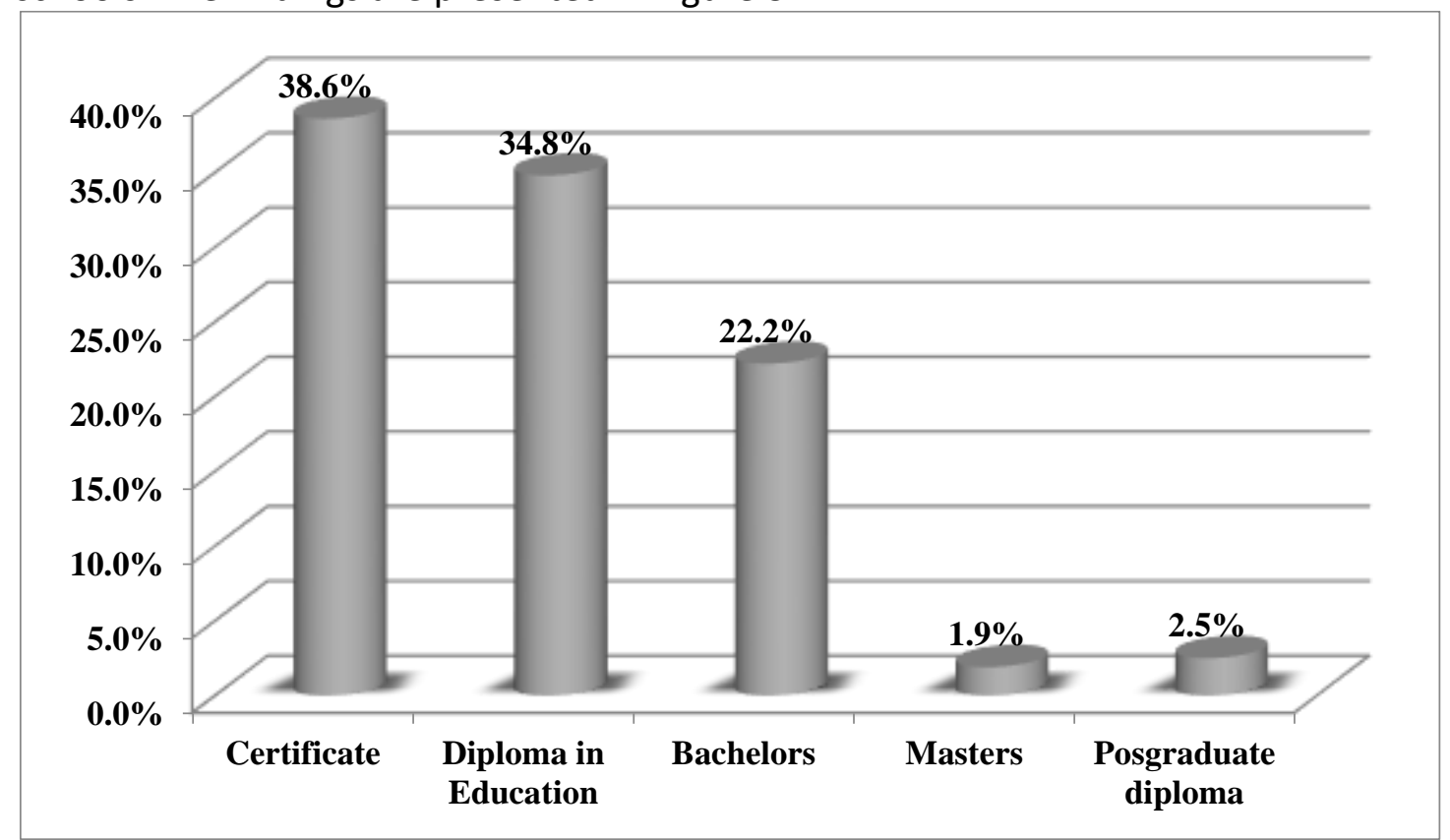

Figure 3 Level of education of teachers

The study findings shows that most 61 (38.6\%) of teachers were certificate holders (involving teachers who held P1, ATS), 55 (34.8\%) were found to hold diploma in education level of training, 35 $(22.2 \%)$ said that they had undergraduate degrees, $3(1.9 \%)$ were found to possess master's degree while $4(2.5 \%)$ indicated that they had postgraduate diploma in Education. The result implies that the education level of teachers in Marakwet is high. 
INTERNATIONAL JOURNAL OF ACADEMIC RESEARCH IN BUSINESS AND SOCIAL SCIENCES

Vol. 10, No. 2, Feb, 2020, E-ISSN: 2222-6990 @ 2020 HRMARS

\section{Working Experience}

The teachers were also asked to give their work experience in teaching in primary schools in the sub county. Their responses are given in Table 4.

Table 4 Teachers working experience

\begin{tabular}{lll}
\hline Range & Frequency & Percent \\
\hline $1-5$ & 34 & 21.5 \\
$6-10$ & 21 & 13.3 \\
$11-15$ & 9 & 5.7 \\
$16-20$ & 27 & 17.1 \\
More than 20 years & 67 & 42.4 \\
\hline Total & $\mathbf{1 5 8}$ & $\mathbf{1 0 0 . 0}$ \\
\hline
\end{tabular}

The results of the study shows that most of respondents 67 (42.4\%) had taught in public primary schools for more than 20 years, $34(21.5 \%)$ said that they have taught for the last $1-5$ years, $27(17.1 \%)$ said it is between 16-20, $21(13.3 \%)$ said that it is between 6-10 years while $9(5.75)$ indicated that the teaching experience spans between 11-15 years. The result implies that respondents had good knowledge and understanding on the FPE policy since they had been there since its introduction in the year 2003. Therefore, the respondents are in a position to give a true effect or impact of the same towards promoting equity in education access in primary schools within the area. The class teachers came all from lower primary and upper primary classes.

\section{Effect of Free Instructional Resources Support on Equity in Access to Primary Education}

This is the last objective of the research that sought to determine the effect of free infrastructural resources provided by government on Equity in access to education in primary schools in Marakwet Sub County. Through a Likert scale of five, (strongly agree (5) to strongly disagree (1)), the teachers were asked to give their responses on the effect of provision of free instructional learning resources on Equity in access to education. The results are presented in Table 5. 
INTERNATIONAL JOURNAL OF ACADEMIC RESEARCH IN BUSINESS AND SOCIAL SCIENCES Vol. 10, No. 2, Feb, 2020, E-ISSN: 2222-6990 @ 2020 HRMARS

Table 5 Effect provision of free instructional resources on Equity in access to education

\begin{tabular}{|c|c|c|c|c|c|c|c|c|c|c|}
\hline \multirow[t]{2}{*}{ Response } & \multicolumn{2}{|c|}{$\begin{array}{l}\text { Strongly } \\
\text { agree }\end{array}$} & \multicolumn{2}{|c|}{ Agree } & \multicolumn{2}{|c|}{$\begin{array}{l}\text { Undecide } \\
\text { d }\end{array}$} & \multicolumn{2}{|c|}{ Disagree } & \multicolumn{2}{|c|}{$\begin{array}{l}\text { Strongly } \\
\text { disagree }\end{array}$} \\
\hline & f & $\%$ & $f$ & $\%$ & f & $\%$ & $f$ & $\%$ & $f$ & $\%$ \\
\hline $\begin{array}{l}\text { Provision of } \\
\text { textbooks has } \\
\text { enabled children to } \\
\text { participate in } \\
\text { learning }\end{array}$ & 115 & 72.8 & 42 & 26.6 & 1 & .6 & 0 & 0.0 & 0 & 0.0 \\
\hline $\begin{array}{l}\text { FPE has ensured } \\
\text { adequate teachers } \\
\text { are provided in our } \\
\text { schools }\end{array}$ & 9 & 5.7 & 30 & 19.0 & 5 & 3.2 & 64 & 40.5 & 50 & 31.6 \\
\hline $\begin{array}{l}\text { The pupils-book ratio } \\
\text { is adequate for all } \\
\text { pupils }\end{array}$ & 31 & 19.6 & 60 & 38.0 & 13 & 8.2 & 49 & 31.0 & 5 & 3.2 \\
\hline $\begin{array}{l}\text { the FPE policy has } \\
\text { ensured provision of } \\
\text { chalks, chalkboards } \\
\text { and other } \\
\text { stationeries for } \\
\text { learning }\end{array}$ & 71 & 44.9 & 70 & 44.3 & 3 & 1.9 & 11 & 7.0 & 3 & 1.9 \\
\hline $\begin{array}{l}\text { The provision of } \\
\text { enough exercise } \\
\text { books had enabled } \\
\text { pupils to progress } \\
\text { with their education }\end{array}$ & 60 & 38.0 & 68 & 43.0 & 8 & 5.1 & 20 & 12.7 & 2 & 1.3 \\
\hline
\end{tabular}

Findings from Table 5 reveal that most 115 (72.8\%) of respondents strongly agreed that provision of textbooks has enabled children to participate in learning, $42(26.6 \%)$ agreed with the result while 1 $(0.6 \%)$ were undecided. This shows that learners' provision of exercise books and textbooks for learning process has enabled them to attend school frequently. However, results of the study revealed that $64(40.5 \%)$ of teachers disagreed while 50 (31.6\%) strongly disagreed with the statement that FPE policy has ensured that adequate teachers are available in schools. Only, 30 (19\%) and $9(5.7 \%)$ of respondents indicated that teacher's adequacy was not an issue in their schools. This shows that teacher ratio to pupils is still a challenge affecting many primary schools in Marakwet sub county.

The PTA and SMC have resorted to employing untrained teachers who support the existing one provided by TSC. For instance, in one school visited, the number of PTA teachers exceeded those employed by TSC. Further, 60 (38\%) agreed and 31 (19.6\%) of teachers strongly agreed that the pupils book ratio was adequate for all pupils in their schools with $49(31 \%)$ disagreeing and $5(3.2 \%)$ strongly disagreeing with the statement. This shows that pupils: book ratio has significantly improved in the 
past 10 years because of FPE policy. However, 33.2\% of schools have not attained the required 3:1 pupils' book ratio.

In addition to the results above, 71 (44.9\%) strongly agreed and 70 (44.3\%) agreed that FPE policy has ensured provision of chalks, chalkboards and other stationeries for learning in their schools, 3 (1.9\%) were undecided on the statement, 11 (7.0\%) disagreed while $3(1.9 \%)$ strongly disagree. This shows that FPE policy has ensured adequate provision of chalks, boards and other stationeries for improving quality of free primary education in Marakwet sub-county primary schools. Lastly, 60 (38.0\%) and 68 (43.0\%) of respondents agreed that the provision of enough exercise books has enabled pupils to progress with their education up to standard eight. Few $20(12.7 \%)$ disagreed while 2 (1.3) strongly disagreed with the statement. This shows that the FPE policy has ensured that exercise books are provided to every pupil to facilitate his/her learning in schools and therefore boost retention and completion patterns in schools. This is consistent with Kenya (2008) who established that quality of education in Migwani division had gone up due to procurement of more reading materials.

Adequacy Teachers Employed by PTA in Primary schools in Marakwet

PTA and BOM have resorted to employ additional teachers to bridge the shortfall that should be filled by those employed by TSC. Therefore, the study sought teachers' opinion as to whether teachers employed by PTA were adequate. The results of the analysis are presented in Figure 4.

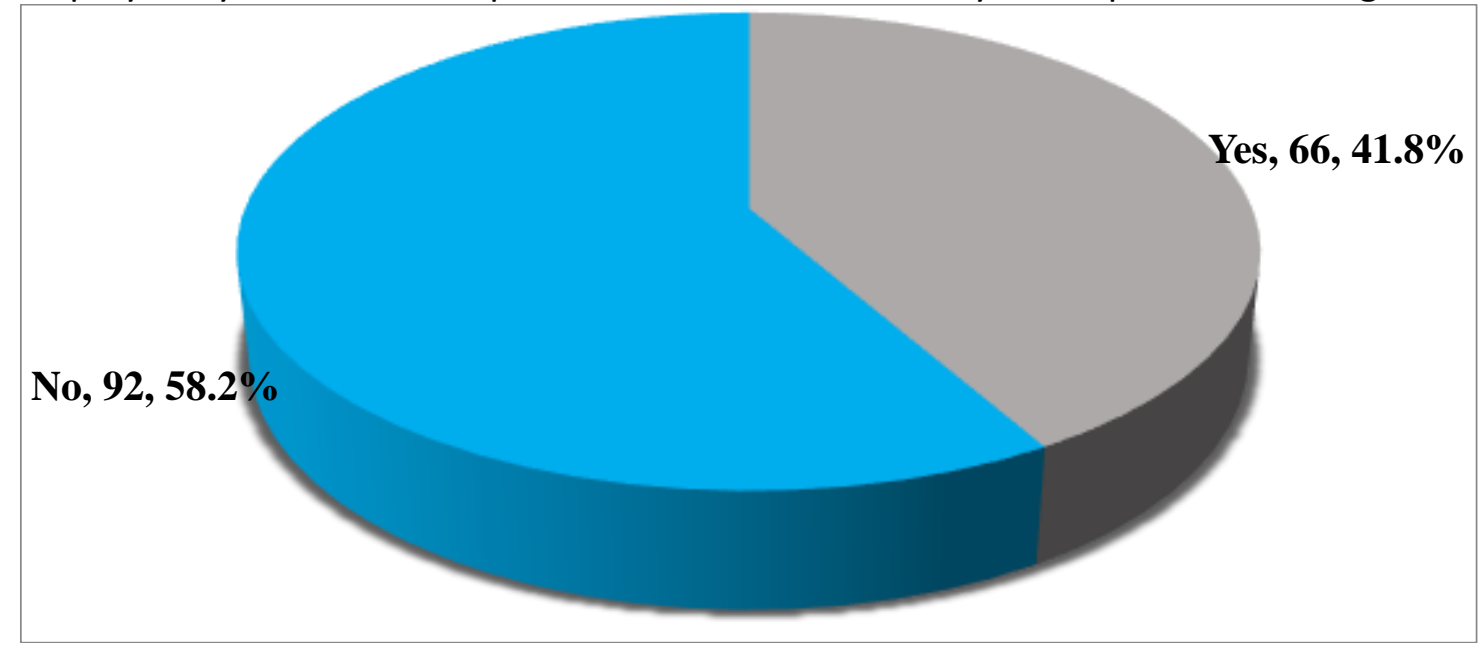

Figure 4 Adequacy of teachers employed by TSC

It is observed that majority $92(58.2 \%)$ of teacher believed that the number employed to fill the gap is not adequate with only $66(41.8 \%)$ indicating that the number is adequate. This shows that despite PTA and BOM members making efforts to address high pupil teacher ratio, the number employed is not sustainable and able to ensure provision of quality and efficient education in primary schools in Marakwet Sub County.

Head teachers' Responses on Influence of FPE Policy on Provision of Instructional Resources on Equity in Education Access in Primary Schools

The study sought head teacher's opinion regarding the influence of FPE policy on the provision of instructional resources on enhancing equity in education access in primary schools. Their responses are given in Table 6. 
INTERNATIONAL JOURNAL OF ACADEMIC RESEARCH IN BUSINESS AND SOCIAL SCIENCES

Vol. 10, No. 2, Feb, 2020, E-ISSN: 2222-6990 @ 2020 HRMARS

Table 6: Head teachers' responses on the influence of FPE policy on provision of instructional resources on equity in education access

\begin{tabular}{|c|c|c|}
\hline Influence & Frequency & Percent \\
\hline It has encouraged learners to read more & 3 & 11.1 \\
\hline It has improved the standard of education in the school & 6 & 22.2 \\
\hline Relieved the burden on parents towards books purchase & 8 & 29.6 \\
\hline Provided adequate materials to schools & 7 & 25.9 \\
\hline $\begin{array}{l}\text { Most teachers can teach orally and practically and thus achieve } \\
\text { their targets }\end{array}$ & 2 & 7.4 \\
\hline $\begin{array}{l}\text { The learners are getting equal access to education regardless of } \\
\text { their background }\end{array}$ & 1 & 3.7 \\
\hline Total & 27 & 100.0 \\
\hline
\end{tabular}

The results reveal that most 8 (29.6\%) of head teachers said that the FPE policy support on instructional resources has relieved burden on parents towards purchase of text and exercise books for their pupils, 7 (25.9\%) said it has provided adequate instructional materials to schools, 6 (22.2\%) indicated that it has improved educational standards in the school, 3 (11.1\%) said that learners can now read more due to availability of textbooks, 2 (7.4\%) opined that most teachers can teach orally and practically and thus achieve their targets while $1(3.7 \%)$ observed that the learners are getting equal access to education regardless of their background or status. The findings are in contrast to Riddell (2003) results that showed that the biggest challenges were, not pressure on classroom facilities, insufficient teachers and an inadequate supply of instructional materials, all areas to which the development community responded, attempting to cater for shortfalls of the order of 38,000 new classrooms and at least 25,000 additional teachers in Malawi primary schools.

Another head teacher remarked the provision of instructional resources has motivated learners that in turn led to retention of pupils in class throughout the term and year. Another one also observed that cases of absenteeism have become very minimal because play materials e.g. balls, wall charts, curiosity charts and real teaching materials has made learning very enjoyable. However, some head teachers noted that the money has been constant since 2003, book prices have increased, and hence it has become less effective. Therefore, children access to instructional resources has been increased as learners can access books without straining much. This has improved academic performance of primary schools in the area.

PTA Members' Responses on Influence of FPE on Provision of Instructional Resources in Attaining Equity in Education Access

The PTA members were asked to give their verdict on how FPE policy provision of infrastructural resources in attaining equity in education access in primary schools in Marakwet Sub County. Here are the responses made by several members interviewed;

The instructional resources have helped a lot and has benefited all pupils equally in the school this because every pupil is able to access books.

Another one opined that: 
INTERNATIONAL JOURNAL OF ACADEMIC RESEARCH IN BUSINESS AND SOCIAL SCIENCES

Vol. 10, No. 2, Feb, 2020, E-ISSN: 2222-6990 ¿ 2020 HRMARS

Children and parents have been spared the burden of buying exercise and textbooks among other stationeries. These resources have helped a lot especially in retention of pupils at school. On equity, one female PTA member observed that:

There has emerged a healthy competition among girl and boy pupils. This is because it has influenced equity in education for both boys and girls. The school results have gone higher because of equal distribution of resources to all pupils.

The findings show that there have been significant changes in terms of educational instructional resources being availed to schools by FPE policy. For instance, schools have now more supplementary books for learning and revision purposes. The instructional materials are now accessible by all members.

However, other PTA members had a different of views in that:

There are less teachers compared to the pupils

Another observed that:

Some head teachers just write and forge invoices and non-instructional materials are bought Another one said that:

There is some change in terms of writing materials but in textbooks, they are not enough hence, more funds needed

However, the findings show that the benefits of the FPE policy have outweigh the challenges that comes with it.

\section{Equity in Access to Primary Education}

This is the main dependent variable for the study that looks at how enrolment, retention and completion patterns of pupils have changed or not after the introduction of FPE policy in primary schools in Marakwet Sub County. At first, the respondents were asked to indicate whether enrolment in their schools has increased, remain stable or decreased after the introduction of FPE. The results are presented in Table 7.

Table 7 FPE and enrolment in primary schools

\begin{tabular}{lll}
\hline Enrolment rate & Frequency & Percent \\
\hline Increased & 154 & 97.5 \\
Decreased & 3 & 1.9 \\
Remained stable & 1 & 0.6 \\
\hline Total & $\mathbf{1 5 8}$ & $\mathbf{1 0 0 . 0}$ \\
\hline
\end{tabular}

Results show that majority 154 (97.5\%) of teachers agreed that enrolment had increased significantly since the introduction of FPE with only $3(1.9 \%)$ indicating that enrolment had decreased while 1 (0.6\%) maintained that nothing had change. This implies FPE has a positive effect on pupils' enrolment rate in primary schools in Marakwet Sub County. In the interview, one head teacher interviewed said that:

FPE has increased enrolment in our school since the parents are relieved the burden of meeting the costs of education.

Another head teacher observed that: 
INTERNATIONAL JOURNAL OF ACADEMIC RESEARCH IN BUSINESS AND SOCIAL SCIENCES

Vol. 10, No. 2, Feb, 2020, E-ISSN: 2222-6990 ¿ 2020 HRMARS

The enrolment in the school has increased since the start of free primary education and most learners complete their studies.

The responses made by head teachers concurs with teachers and PTA responses that indicated that enrolment increased in primary schools as a result of the introduction of FPE.

\section{Participation of Pupils from Poor Background}

As one measure of equity in education access, the study sought to find out whether the participation of pupils from poor backgrounds was the same as those from well to do households. The results are given in Table 8.

Table 8 Participation of pupils from poor background

\begin{tabular}{lll}
\hline Response & Frequency & Percent \\
\hline Yes & 103 & 65.2 \\
No & 55 & 34.8 \\
\hline Total & $\mathbf{1 5 8}$ & $\mathbf{1 0 0 . 0}$ \\
\hline
\end{tabular}

According to findings from Table 8, most 103 (95.2\%) of teachers acknowledged that FPE has enabled pupils from poor backgrounds to access to primary education in Marakwet sub county while 55 (34.8\%) maintained that there is inequality in access by pupils from poor backgrounds due to the fact that most of them cannot afford to pay the additional costs of infrastructure development, meals and hiring of teachers in primary schools. on their part, the PTA members said that all children (orphans and those from poor and impoverished backgrounds) have benefited by accessing the education for free in public primary schools. however, one PTA member observed that children who are disabled have not benefited from FPE policy.

\section{Head teachers' Responses on FPE and Participation of Boy/girl Child in Primary Education}

The PTA members were also asked whether there existed differences between girl and boy child access and retention in schools because of introduction of FPE. The results are presented in Table 9.

Table 9 Head teachers' responses on FPE and participation of boy/girl child in primary education

\begin{tabular}{lll}
\hline Beneficiary & Frequency & Percent \\
\hline Boy & 4 & 14.8 \\
Girl & 14 & 51.9 \\
Both & 9 & 33.3 \\
\hline Total & $\mathbf{2 7}$ & $\mathbf{1 0 0 . 0}$ \\
\hline
\end{tabular}

Responses from head teachers (Table 9) show that at least 14 (51.9\%) said that girl-child has benefited from FPE, 9 (33.3\%) observed that both categories of pupils have benefited while only 4 (14.8\%) indicated that they boy-child has benefited from FPE policy. The result implies that the girlchild as the main beneficiary of FPE policy. This could be because the government and other stakeholders have been agitating for the right to education for the girl-child in the past decade. 
INTERNATIONAL JOURNAL OF ACADEMIC RESEARCH IN BUSINESS AND SOCIAL SCIENCES

Vol. 10, No. 2, Feb, 2020, E-ISSN: 2222-6990 @ 2020 HRMARS

Head teachers' Responses on how Learners have benefited from FPE Policy in Enhancing Equity in Access

The head teachers were also asked to give their perception on how FPE policy has influenced pupils' access to primary education regardless of their background. The results are presented in Table 10.

Table 10 Head teachers' responses on how learners have benefited from FPE policy in enhancing equity in access

\begin{tabular}{|c|c|c|}
\hline Beneficiaries & Frequency & Percent \\
\hline Children from poor families have greatly benefitted & 4 & 14.8 \\
\hline All pupils benefit & 8 & 29.6 \\
\hline $\begin{array}{l}\text { Orphans, single parental pupils and poor have utilized this } \\
\text { opportunity more }\end{array}$ & 15 & 55.6 \\
\hline Total & 27 & 100.0 \\
\hline
\end{tabular}

Results in Table 10 show that most 15 (55.6\%) of head teachers said that orphans, children from single parent households and those from poor backgrounds benefit more in access to primary education, 8 (29.6\%) said that all children have benefited while 4 (14.8\%) said that children from poor families have greatly benefitted from free primary education policy. The findings are consistent with Kenya (2008) research findings in Migwani Division, Kitui County that revealed that more poor families have been able to send children to school, although the school still reports some children dropping out due to hardships.

\section{Completion Rate of Pupils in Primary School}

Still as another indicator of equity in access to primary education, the respondents were asked whether all the pupils in their school remained until the end of class 8 . Their responses are given in Table 11.

Table 11 Completion rate of pupils in primary school

\begin{tabular}{lll}
\hline Response & Frequency & Percent \\
\hline Always & 39 & 24.7 \\
Occasionally & 82 & 51.9 \\
Rarely & 30 & 19.0 \\
Never & 7 & 4.4 \\
\hline Total & $\mathbf{1 5 8}$ & $\mathbf{1 0 0 . 0}$ \\
\hline
\end{tabular}

Results in Table 11 show that $82(51.9 \%)$ said that majority of pupils occasionally remain in school until completion of primary education at Standard 8, 39 (24.7\%) said that they always remain, 30 $(19 \%)$ said that they rarely remain in school while $7(4.4 \%)$ said that some pupils in their school do not complete their primary education. The main cause for pupils not completing their primary education in time is due to early pregnancy (50.0\%) and drop out due to fees problem (13.9\%). 
INTERNATIONAL JOURNAL OF ACADEMIC RESEARCH IN BUSINESS AND SOCIAL SCIENCES Vol. 10, No. 2, Feb, 2020, E-ISSN: 2222-6990 @ 2020 HRMARS

\section{PTA Responses on the Success of FPE on Enrolment, Retention and Completion Rate in Schools}

The PTA members through interview were asked to give the success of FPE towards promoting enrolment, retention and completion rate in primary schools in Marakwet Sub County. One PTA member remarked that:

It has increased enrolment, boosted retention and increased completion rate in primary schools in this area.

Another one said that:

The children have greatly benefitted because they have gotten instructional materials and other support services.

While another female PTA member observed that:

Many pupils have been enrolled since then, because some necessities of learning like books, pen, and etc was a challenge to parents and guardians before it was free.

However, one PTA members had a different opinion in that he mentioned:

There is improved enrolment and retention is poor due to levies to meet lunch expenses and PTA money

The opinion of PTA members underscores the importance of Free Primary Education towards improving access to primary schools in Marakwet Sub County. However, the issue of extra charges appears (lunch, PTA, and development fee) amongst some schools and this has been blamed to affect retention of pupils. The positive observation is that high enrolment was achieved after introduction of free primary education but retention and completion challenges remain. Nyaegah, (2011) found out that the introduction of FPE increased the number of pupils' enrolment in primary schools. This is viewed as one of the challenges facing the management of primary schools.

\section{Influence of Free Primary Education Policy on Equity in Education Access in primary schools in Marakwet Sub County}

As the main theme of the study, it was important to determine the extent to which FPE policy has ensured equity in education access in primary schools in Marakwet Sub County by conducting a multiple linear regression

\section{Summary, Conclusions and Recommendations Summary of the Findings Effect Provision of Free Instructional Resources on Equity in Access to Primary Education}

According to respondents' provision of free learning resources had ensured that learners read more widely and were able to participate in schoolwork activities throughout the academic year. On their part, the teachers said that provision of textbooks and stationeries had improved the teaching environment. However, provision of enough teachers in schools is still a challenge to realization of universal primary education resolutions is achieved in primary schools in Marakwet Sub County. More than half of the teachers said that the book ratio had improved significantly and this has made learners to read widely. The head teachers on their part indicated that the parents have been spared the burden of purchasing instructional materials, the classroom environment has changed and now there is incorporation of theory and practical approaches and PTA members on their part said that all learners irrespective of their background benefited from instructional resources provided to them. This has promoted equality amongst all children. They further said that healthy competition has 
INTERNATIONAL JOURNAL OF ACADEMIC RESEARCH IN BUSINESS AND SOCIAL SCIENCES

Vol. 10, No. 2, Feb, 2020, E-ISSN: 2222-6990 @ 2020 HRMARS

emerged between boys and girls in the school. Others said that the performance has increased significantly. This is in support by statistics from zonal education offices that showed that performance has been increasing steadily across public primary schools in the area.

\section{Conclusion of the Study}

The study concluded that government has slightly supported school resources repair, expansion and construction of new ones but majority of respondents reported that the facilities in the schools were outstretched due to high number of pupils enrolled. This has forced some schools to combine and shift classes to accommodate the large number of pupils. To bring the attentions of all stakeholders to address the different needs of learners in order to get a total free access of education

\section{Recommendations of the Study}

The government needs to employ more teachers to bridge the current shortage. In addition, replacement of teachers who leave the profession under natural attrition is important to ensure that quality learning takes place

\section{References}

Ahmed, R., \& Sayed, Y. (2009). Promoting Access and Enhancing Education Opportunities? The Case of 'no-fees Schools' in South Africa. Compare: A Journal of Comparative \& International Education, 39(2), 203-218.

Avenstrup, R., Liang, X., \& Nellemann, S. (2004) Kenya, Lesotho, Malawi and Uganda: Universal primary education and poverty reduction: A case study from reducing poverty- what works, what doesn't and why. [Conference paper]. Washington, DC: World Bank.

Bategeka, L. (2005). Universal primary education (UPE) in Uganda. Report to the Interregional inequality facility-policy case study. Uganda, Institute of Development Studies, University of Sussex.

Chimombo, J. P. G. (2005). Issues in Basic Education in Developing Countries: An Exploration of Policy Options for Improved Delivery. Journal of International Cooperation in Education, 8 (1), 129152.

Creswell, J. W. (2003). Research Design: Quantitative, Qualitative and Mixed Method Approaches. London: Sage Publication Thousand Oaks.

Deininger, K. (2003). Does the cost of schooling affect enrollment by the poor? Universal primary education in Uganda. Economics of Education Review, 22(3), 291-305.

Fafunwa, B. (2001). Educational management in Nigeria. Current Issues in Educational Management in Nigeria, NAEAP Publication, Lagos, 1-12.

Field, S., Kuczera, M., \& Pont, B. (2007). No More Failures: Ten Steps to Equity in Education, OECD, Paris.

Gall, M., \& Borg, M. (1996). Education Research: An Introduction. New York: Longman.

Glewwe, P., \& Kremer, M. (2006). Schools, teachers, and education outcomes in developing countries. Handbook of the Economics of Education, 2, 945-1017.

Gregory, R. J. (1992). Psychological testing: History Principles and Application. Boston: Allyn and Bacon. 
INTERNATIONAL JOURNAL OF ACADEMIC RESEARCH IN BUSINESS AND SOCIAL SCIENCES

Vol. 10, No. 2, Feb, 2020, E-ISSN: 2222-6990 @ 2020 HRMARS

Harbison, R. \& Hanushek, E. (1992). Education Performance of the Poor: Lessons from Northeast Brazil. New York: Oxford University Press.

Hirth, M. A., \& Eiler, E. (2005). Horizontal and vertical equity analysis of Indiana's 2001 reward-foreffort formula. Journal of Education Finance, 30(4), 382-398.

Joseph, O. O., \& Francis, K. (2015). The influence of organizational culture and market orientation on performance of microfinance institutions in Kenya. International Journal of Business and Management, 10(8), 204.

Kenya, P. (2008). An assessment of the Impact \& Sustainability of free primary education in Migwani Division Kenya. A master of arts Thesis. Oxford: Oxford brokers university.

Kerlinger, F. N. (1986). Foundations of Behavioural Research. Harcourt Brace, Jovanovich.

Kikechi, W., Andala, P., Chepkwony, S. \& Simiyu, S. (2012). Factors Affecting the Access of Free Primary Education by Gender in Kenya. Journal of Educational and Social Research, 2 (2).

Kombo, D. K., \& Tromp, D. L. (2006). Proposal and thesis writing: An introduction. Nairobi: Paulines Publications Africa, 5, 814-30.

Kremer, M., Moulin, S., \& Namunyu, R. (2002). Unbalanced decentralization. Harvard University. Cambridge, MA. Available on line at http://econ. bu. edu/dilipm/40-kremounam. pdf. Processed.

Limukii, K. E., \& Mualuko, N. J. (2012). The Free Education Policy in Kenya: A Critique. International Journal of Educational Administration and Policy Studies, 4(1), 1-5.

Lutz, W., Cuaresma, J. C., \& Sanderson, W. (2008). The demography of educational attainment and economic growth.

Makori, A. (2005). The Kenya's educational policy: Exploring some of the major impediments to redesigning pedagogy. In Proceedings of the International Conference.

Miller, D. (2005). 'What is Social Justice?' in Pearce, N. and Paxton, W. Eds. Social Justice: Building a Fairer Britain London: Politico's.

Mugenda, O., \& Mugenda, A. (1999). Research Method: Quantitative and Qualitative Approaches. Nairobi: Nairobi African Center for Technology.

Njeru, E. H. (2013). The Status, Interpretation and Opportunities for Gender Equity in the Kenyan Educational System. Norag News, p.61-66.

Nussbaum, M. (1999). The professor of parody. The new republic, 22(2), 37-45.

Nyaegah, J. O. (2011). Principals' and students' attitudes towards guidance and counselling services in the management of secondary schools of Kisii County, Kenya. International Journal of Business and Management Tomorrow, 1(2), 1-10.

OECD. (2001a). Education Policy Analysis. Paris: OECD.

Oketch, M., \& Ngware, M. (2010). Free primary education still excludes the poorest of the poor in urban Kenya. Development in Practice, 20(4-5), 603-610.

Orodho, A. J. (2003). Essentials of educational and social sciences research method. Nairobi: Masola Publishers.

Psacharopoulos, G., \& Woodhall, M. (1985). Education for Development: An Analysis of Investment Choices. Oxford: Oxford University Press.

Raja, B., \& Burnett, N. (2004). User fees in primary education. Washington, DC: World Bank.

Rawls, J. (2001). Justice as fairness: A restatement. Harvard University Press. 
INTERNATIONAL JOURNAL OF ACADEMIC RESEARCH IN BUSINESS AND SOCIAL SCIENCES

Vol. 10, No. 2, Feb, 2020, E-ISSN: 2222-6990 @ 2020 HRMARS

Republic of Kenya [RoK] (2005). A Policy Framework for Education, Training and Research: Meeting the challenges of education, training and research in Kenya in the $21^{\text {st }}$ Century. Nairobi: Ministry of Education, Science, and Technology.

Riddell, A. (2003). The introduction of free primary education in sub-Saharan Africa. Background paper prepared for the Education for All Global Monitoring Report 2003/4. UNESCO.

Riddell, A. (2003). The introduction of free primary education in sub-Saharan Africa. Background paper prepared for the Education for All Global Monitoring Report 2003/4. UNESCO.

RoK. (2014). Marakwet Sub County Education Statistics. Kapsowar Sub County Education office.

Toutkoushian, R. K., \& Michael, R. S. (2007). An alternative approach to measuring horizontal and vertical equity in school funding. Journal of Education Finance, 395-421.

UNESCO. (2003). Gender and Education for All: The leap to equality. Paris, UNESCO: 274.

UNESCO. (2005). Challenges of implementing free primary education in Kenya. UNESCO Assessment Report, March 2005.

Williams, T. P. (2015). Great Expectations: Children's Education in Rural Rwanda. Reading, UK: CfBT Education Trust.

World Bank. (2004). School fees. A Road Block to EFA. Education notes. Washington D.C. World Bank. 